\title{
“UMA TERRA SEM AMOS": O FEDERALISMO na Comuna de Paris
}

Alexandre Samis*

asamis@uol.com.br

Resumo: O texto aborda as raízes da tradição federalista na França, em especial, durante a Comuna de Paris. Busca elucidar as formas organizativas presentes na capital francesa, antes e durante os 72 dias nos quais Paris esteve mergulhada em um movimento revolucionário de enorme significado social. A ação dos membros da Associação Internacional dos Trabalhadores é igualmente retratada, assim como a contribuição dessa grande entidade para a constituição de um poder operário edificado em Paris a partir dos distritos e bairros.

Palavras-chave: federalismo, internacionalismo, Comuna de Paris, revolução, poder operário.

Entre abril e maio de 1871, no contexto da Guerra Civil francesa, o ministro das Relações Exteriores de Versalhes, Jules Favre, afirmava que a Comuna pregava um ideal medieval e retrógrado, uma vez que se proclamava federalista, forma esta tomada pela autoridade de chancelaria como reminiscência de um passado a ser superado. Redarguia que, ainda mais obtusos que os jacobinos de 1793, os communards eram federalistas celerados: postulavam uma pátria cindida e em muitos pedaços, tanto mais inúteis por se constituírem de baixo para cima. Configuração anacrônica e patética em um século no qual "todas as nações tendiam à unidade política". Para o ministro, com a intenção de anátema, era uma verdadeira "Vendeia socialista" (KoECHLIN, 1965, p. 81).

Tal juízo - para reforço do qual Favre se valeu de referências concernentes ao período inaugurado em 1789 - não objetivava apenas a condenação da oposição política da Comuna aos membros da Assembleia em Versalhes, mas (e talvez resida aí sua mais clara indisposição em relação

\footnotetext{
* Doutor em História pela UFF. Professor no Colégio D. Pedro I. Autor do livro: Negras tormentas. O federalismo e o internacionalismo na Comuna de Paris, Hedra, 2011.
} 
aos fatos) uma incontida ira diante da impertinência popular ao ousar governar a capital da França. A oposição, pelo exposto, não se restringia à condenação de um tipo de organização das unidades sociopolíticas em um mesmo território nacional, visto que os moderados girondinos já haviam reivindicado o federalismo durante a Grande Revolução (Koechlin, 1965, p. 121). Antes de tudo, havia uma clara hostilidade ao projeto popular daqueles que, por força da experiência acumulada a partir de 1830, lançavam mão da forma federalista de organização.

No que corresponde aos operários franceses, em particular os parisienses, a orientação federalista já havia sido mais claramente adotada nos fóruns da Associação Internacional dos Trabalhadores, como consequência dos memoráveis debates nos quatro primeiros congressos da entidade: em Genebra (1866), Lausanne (1867), Bruxelas (1868) e Basileia (1869). Nesses encontros, primeiro os mutualistas, seguidos pelos coletivistas reforçaram a necessidade de se garantir a autonomia das várias seções da Internacional espalhadas pela Europa, não apenas frente ao Conselho Geral sediado em Londres (que para os federalistas deveria restringir-se à função organizativa), como ainda aos bureaux em cada um dos países filiados. Segundo esse raciocínio, o Bureau de Paris deveria assumir funções análogas às do Conselho Geral, assim como os seus congêneres localizados nas demais unidades nacionais.

O projeto não ficava restrito ao âmbito da organização espacial e política; primava antes pela articulação entre os entes econômicos, aqueles que deveriam forçosamente se pôr em acordo pela identidade de classe, dessa forma, gerindo as unidades produtivas. Essa era uma questão central e estratégica, principalmente por encontrarem-se os federalistas revolucionários ancorados tanto nas prédicas de Pierre-Joseph Proudhon, como nas experiências concretas teorizadas pelo referido mestre de Besançon. Menos por ardor doutrinário, e mais pela observância de diversas iniciativas (já endêmicas por toda a França e partes da Bélgica e Suíça), esses federalistas acreditavam que era tempo de unir as diversas esferas da sociedade sob a bandeira da economia. Segundo Proudhon (1947, p. 249):

Nenhum dos partidos que existem no século XIX, nem sequer o que invoca a tradição jacobina, é revolucionário: [...] A revolução, se sabe hoje que é: o trabalho para o operário, a terra para o camponês, a independência para os cidadãos, para as comunas, para os departamentos; a igualdade social e a propaganda, armada se necessário, no exterior. 
Não por acaso, os operários ligados à Internacional na França encontraram poucos motivos para cerrar fileiras ao lado dos jacobinos.

Para os que liam Proudhon (1947) pelo viés revolucionário, fazia sentido, antes de tudo, a seguinte reflexão:

O problema consiste, pois, para as classes trabalhadoras, não em conquistar, mas em vencer de uma vez o poder e o monopólio, o que quer dizer fazer surgir das entranhas do povo, das profundezas do trabalho, uma atividade maior, um feito mais poderoso que envolva o capital, o Estado e que os subjugue. Toda a proposição de reforma que não satisfaça essa condição não é mais que um açoite, uma virgem de sentinela, virgam vigilantem, dizia o profeta, que ameaça o proletariado. (p. 129)

E ainda: "A esperança de levar a cabo pacificamente [...] a abolição do proletariado é uma utopia" e "sou do partido do Trabalho contra o partido do Capital".

Dentro da Internacional, mais claramente nos Congressos de Bruxelas e Basileia - pautados não apenas nas ideias de Proudhon, mas também nas de outros, como Eugéne Varlin, Benoît Malon e do belga César De Paepe - todos os operários egressos das seções francófonas ganharam força naquela que viria a ser conhecida como vertente coletivista do socialismo. Tal orientação (além das citadas perspectivas, entre as quais se destaca o federalismo) converteria inclusive o revolucionário russo Mikhail Bakunin quem, muito depressa, tornar-se-ia um de seus mais importantes divulgadores. ${ }^{1}$

Bakunin (que havia ficado cerca de uma década afastado das atividades revolucionárias, por conta de um rigoroso regime prisional e posterior desterro para a longínqua Sibéria) encontrou na Internacional um fértil terreno para a sua pregação insurrecional. Baseada em sociedades secretas - boa parte das quais em território italiano, articuladas primeiro na Fraternidade Internacional, depois na Aliança da Democracia Socialista, esta última fundada em 1868 - a estratégia defendida pelo revolucionário russo encontrava-se igualmente no campo federalista. E, muito provavelmente, também por esse motivo, atraiu para as suas fileiras nomes como Varlin e Malon.

No interior da Internacional, o coletivismo (expressão orgânica de um determinado setor operário) acabaria por servir à Bakunin, simultaneamente, como meio para convencer uma parcela expressiva de militantes e como campo de observação a partir do qual foi possível a ele, animado por experiências práticas, estabelecer contornos mais precisos à sua teoria revolucionária. Fato este que acabaria por distanciá-lo, sobremaneira, do 
diálogo que até então mantinha com Marx. Diferente de antes (quando a orientação centralista deste parecia representar um óbice menor, se comparado às inúmeras afinidades), para Bakunin, principalmente após o Congresso da Basileia, a oposição devia ser apresentada nos seguintes termos:

Eu detesto o comunismo porque ele é a negação da liberdade e porque não posso conceber nada de humano sem liberdade. Não sou absolutamente comunista, porque o comunismo concentra e faz absorver todas as forças da sociedade no Estado, porque ele desemboca necessariamente na centralização da propriedade nas mãos do Estado, enquanto que eu quero a abolição do Estado - a extirpação radical desse princípio de autoridade e da tutela do Estado, que, sob o pretexto de moralizar e civilizar os homens, até este dia os subjugou, oprimiu, explorou e depravou. Eu quero a organização da sociedade e da propriedade coletiva de baixo para cima, pela via da livre associação, e não de cima para baixo por meio de qualquer autoridade que seja. Ao desejar a abolição do Estado, quero a abolição da propriedade individualmente hereditária, que não é outra coisa senão uma instituição do Estado, uma consequência do princípio do Estado. Eis em que sentido sou coletivista e de forma alguma comunista. ${ }^{2}$

Boa parte do que afirma Bakunin é patrimônio comum do coletivismo francês.

\section{As seções da Internacional, os clubes e a Guarda Nacional}

Por toda a França, entre 1866 e 1870, a Internacional havia crescido significativamente. No ano de 1870, em Paris, distribuídas pela cidade, havia cerca de 30 seções (BRUhat et al., 1970, p. 165). Os distritos com maior concentração de seções eram o $4^{\circ}, 5^{\circ}, 10^{\circ}, 11^{\circ}, 13^{\circ}$ e o $17^{\circ}$. Segundo alguns autores, com base em inquéritos policiais e mesmo em números alegados pela própria Internacional, de 500 partidários, em seu primeiro congresso, a organização teria chegado a $245 \mathrm{mil} \mathrm{em} 1870 .^{3}$ As adesões ao Bureau de Paris, por conta de tal fenômeno, passaram a ser feitas em bloco, principalmente no ano de 1869 , período que registra uma curvatura ascendente de greves em todo o país. Seguindo essa tendência, na capital e em áreas da província, as sociedades operárias uniram-se em câmaras federais. Pela primeira vez os operários tentaram organizar-se, de forma horizontal, em federações de ofício e, verticalmente, em uniões regionais. Animando tais iniciativas, encontravam-se militantes dedicados e abnegados, na sua esmagadora maioria ligados, direta ou indiretamente, à Internacional. Entre os muitos anônimos que emprestaram suas energias ao projeto revolucionário 
encontravam-se: Héligon, André Murat, Combault, Émile Aubry, Albert Richard, Bastelica, Malon, Johannard, Avrial, Frankel, Albert Theisz e Varlin; todos internacionalistas.

No quadriênio referido, a Internacional havia sofrido na França duas grandes investidas do governo, com resultados nefastos para os principais militantes que compunham o Bureau de Paris. A primeira, em 1868, que jogando a Internacional na clandestinidade - marcou igualmente o declínio da corrente mutualista. A segunda, em 1870, já no período de prestígio do coletivismo, embora com as mesmas características, só não prejudicou mais a organização dos internacionalistas por contar a entidade com forças superiores às que possuía nos anos anteriores.

A despeito da perseguição levada a efeito pelas autoridades do II Império, os coletivistas ganharam enorme espaço na França. Em relação aos mutualistas, não se tratava apenas de uma modulação no discurso, mas de um deslocamento da raiz metodológica, expressa não apenas pelos meios através dos quais deveriam os militantes se valer para operar a tão sonhada ruptura; a diferença era mais profunda. A geração mutualista havia interpretado os escritos de Proudhon pelo viés reformista e estava, antes de tudo, preocupada em operar transformações mediadas pela ordem. Nesse sentido, os coletivistas - entre eles, com destaque, Varlin - mostraram-se mais ousados. Assumiram uma tendência já majoritária na AIT: uma orientação com sentido de ruptura radical, com fisionomia de guerra de classe; além da condenação mais evidente das mediações com as instituições, substituía também, no vocabulário, o antigo discurso mutualista.

Na mesma proporção das seções da Internacional, cresceu também a popularidade dos clubes revolucionários. Estes, que têm a sua origem no século anterior, eram conhecidos também pelo termo "sociedades" e podiam ser de caráter público, semiprivado ou secreto (PÉRONNET, 1988, p. 62). Diferente das seções, os clubes não possuíam identidade operária definida; eram, antes de tudo, pólos de discussão política nos quais podiam ser encontrados segmentos da pequena burguesia em associação com trabalhadores manuais. Eram centros de agitação nos quais circulavam algumas teses contra o governo e debatiam-se possíveis ações coletivas contra as autoridades, ou mesmo medidas tomadas por elas. Embora tenham permanecido fechados durante boa parte do II Império, ainda que alguns funcionassem clandestinamente, a lei de 6 de junho de 1868 (editada pelo governo com o fito de reforçar uma fina camada democrática de que Napoleão III pretendia revestir seu regime) devolveu aos clubes sua liberdade formal. 
Muito rapidamente eles se multiplicaram em Paris, sem dúvida estimulados pela conjuntura particularmente agitada. Possuíam uma estrutura político-administrativa formada por um bureau, cuja composição incluía um presidente e dois assessores, responsáveis não apenas pela disciplina da plenária durante os debates, como também por zelar pela ordem do dia. Quase sempre o presidente era um notório tribuno, conhecido da maioria dos frequentadores e que gozava do respeito ou da confiança da maioria. Era, portanto, nesses ambientes que se urdiam as alianças, formavam-se os grupos e, de lá mesmo, partiam as massas para engrossar passeatas e concentrações nas praças de Paris ; onde, também, os oradores da Internacional faziam inúmeras exposições de suas reivindicações e ampliavam, por força dos fatos, as bases da organização.

No período entre 1868 e 1870 chegaram a funcionar na capital 63 clubes, em locais variados, como salões, cafés-concerto, teatros, circos, vinícolas, e outros (Dalotel, Faure e Freiermuth, 1980, p. 44). O FoliesBelleville, no $20^{\circ}$ distrito, chegou a receber em um único dia 6 mil pessoas. Outro dado diz respeito ao aumento das reuniões e de clubes nos bairros periféricos - locais frequentados principalmente por operários - nos anos de 1869 e 1870.

Esses clubes foram as formas mais eficientes de capilarização das iniciativas dos revolucionários na conquista de posições estratégicas e, mesmo, o ponto de partida para a formação das federações, como o "Comitê Central Republicano de Defesa Nacional dos Vinte Distritos de Paris". Organizado pelos frequentadores dos clubes, durante o cerco dos prussianos a Paris em 1870, para fiscalizar as ações do governo de Defesa Nacional à semelhança das seções da Internacional, tal Comitê Central recebia as orientações necessárias das suas unidades federadas nos bairros e a elas devolvia, sob forma de proclamas, as deliberações gerais sobre os assuntos de maior importância.

Nessa mesma época, em particular durante o cerco a Paris, um outro segmento social, a Guarda Nacional, sofreu algumas transformações. Desde a sua criação, no verão de 1789 , que a instituição adotava a forma federalista, atitude tanto mais clara após o juramento de assistência mútua, prestado pelas várias Guardas espalhadas pela França em novembro daquele ano. $\mathrm{Na}$ Festa da Federação, por ocasião do 14 de julho de 1790, a Guarda Nacional não apenas ganhou da Assembleia Nacional Constituinte o reconhecimento institucional, como ainda ampliou seu contingente para 14 mil homens (PÉronnet, 1988, p. 149). Passou igualmente a eleger seus oficiais, assim 
como se tornou, pelo conjunto, uma das mais evidentes representações da Nação unida em seus departamentos.

$\mathrm{Na}$ sua trajetória, todavia, a Guarda Nacional serviu muito mais aos propósitos dos governos, quase sempre contra o povo; como no caso da repressão aos religiosos do Midi (Languedoc), entre 1790 e 1793; no terror "branco" e "azul" da Primeira Restauração; contra os canuts em Lyon, durante a Monarquia de Julho (Dupuy, 2010, p. 15); e ainda no massacre dos operários, em Paris, durante as jornadas de junho de 1848. Tendência essa que se alteraria em 1870 .

Poucos dias após a derrota de Napoleão III, em Sedan, no dia 2 de setembro, já no contexto da República, a Guarda Nacional ampliou seu contingente em 60 novos batalhões, fenômeno que só se fez crescer nos meses seguintes, chegando a instituição a somar, na capital, 254 batalhões no início de 1871 (NöEL, 1978, p. 308). A esmagadora maioria dos recémcriados batalhões aparecia nos bairros periféricos, aqueles incorporados aos antigos 14 distritos após a reforma do Barão Haussmann, em 1859. Eram, portanto, formados essencialmente por operários. Haviam surgido também comitês de batalhão, uma evolução do que fora os "conselhos de família" na época da Monarquia de Julho. Esses comitês, formados pelos próprios guardas, passaram a cuidar dos fundos de solidariedade, do abastecimento de gêneros de primeira necessidade e mesmo das armas e munições. Fato que ampliava muito o poder desses órgãos de base, até mesmo sobre seus comandantes (DupuY, 2010, p. 517).

Foi da relação estabelecida entre os comitês, mais solidamente constituídos durante o cerco imposto pelos prussianos a Paris, entre setembro de 1870 e janeiro de 1871, que surgiu um Comitê Central o qual passou a se reunir na sala $d u$ Tivoli-Vauxhall. Em fevereiro, segundo Roger Dupuy (p. 517), era este organismo que controlava de fato a capital. Mesmo o governador de Paris, Joseph Vinoy, e com ele os subprefeitos dos distritos, diante do Comitê Central, eram apenas autoridades nominais.

Frente a tal situação, a Assembleia Nacional eleita no início de fevereiro - estabelecida em Bordeaux e formada por maioria conservadora manifestou, segundo o juízo da maioria, sua preocupação diante do escandaloso fato. Os "rurais" (forma pejorativa pela qual eram tratados os parlamentares em Paris) temiam o estabelecimento de um duplo poder na capital. Desconfiavam da procedência dos membros do Comitê Central, tanto mais por serem operários anônimos, muitos dos quais republicanos radicais ou socialistas. Na realidade os temores não eram infundados. 
No dia 3 de março, uma assembleia convocada pelos membros do órgão diretivo reuniu delegados de 200 batalhões. Como resultado prático, deliberou-se pela formalização de uma federação de batalhões, localizados nos distritos, representados pelo Comitê Central da Guarda Nacional. ${ }^{4}$ Em um segundo encontro, uma semana após, ratificava-se o estabelecimento de três instâncias organizativas, formadas da base até o vértice. Primeiro as delegações nos batalhões, depois nas legiões e por fim no próprio Comitê Central. Funções que não eram apenas eletivas, mas revogáveis a qualquer momento.

No mesmo dia, 10 de março, a Assembleia, agora sediada em Versalhes, votava o fim da moratória dos aluguéis, estabelecida durante o cerco prussiano, e decidia pela suspensão dos soldos dos guardas nacionais; medidas essas claramente retaliatórias. Como complemento, na tentativa de restabelecer o poder de fato, Vinoy entregou o comando da Guarda Nacional ao general Louis d'Aurelle de Paladines, quadro superior do exército, muito impopular entre os guardas.

No geral, a política do governo em relação a Paris era a seguinte: os jornais conservadores (os mesmos que haviam ajudado a eleger a maioria "rural" para a Assembleia) insistiam em estigmatizar a capital. Negavam os sofrimentos do cerco e culpavam os parisienses pelas revoltas de 31 de outubro e de 22 de janeiro ${ }^{5}$ que teriam posto a perder os planos de Trochu e Ducrot. ${ }^{6}$ Um longo trabalho, por parte das elites da província, e que dera muito resultado em fevereiro, tratava de criar uma polaridade na qual Paris ocupava o extremo negativo. Pouco ou quase nada se sabia na província sobre as condições dos parisienses durante os meses do sítio. Uma capital elitista, alheia aos interesses da nação, era assim apresentada aos cidadãos do resto da França. Por tudo isso, fazia-se necessário que os próprios parisienses tratassem de enunciar o conteúdo de seu martírio recente, ou, antes, traçar as metas a serem atingidas não apenas na direção de sua plena superação, como também impedir que a "maioria rural" viesse, novamente, a colocar em risco a República (Lissagaray, 1991, p. 70).

Como parte do compromisso assumido com o chanceler prussiano Otto von Bismarck, após as preliminares do armistício, em 26 de fevereiro, o chefe do executivo - Adolph Thiers - precisava reassumir o controle militar de Paris. Para tanto, elaborou com seu Estado-Maior um plano para sequestrar os canhões e demais armamentos pesados em posse da Guarda Nacional. Com esse fim, no dia 18 de março, alguns destacamentos do exército saíram de seus quartéis com ordens de ocupar Buttes-Chaumont, Belleville, le Temple, Bastilha, Hôtel de Ville, Montmartre, Luxemburgo e 
Inválidos. O Comitê Central da Guarda Nacional, ainda que com pouca mobilização, não apenas reagiu prontamente à investida, como acabou por merecer o apoio de parte das tropas regulares, envolvidas na ação patrocinada pelo governo. Os soldados enviados por ele, igualmente insatisfeitos com a Assembleia, passaram a confraternizar com os guardas e o resultado foi não apenas o insucesso dos planos do governo, como também a execução sumária dos dois generais responsáveis pela missão: Lecomte e Clément Thomas (DolléANs, 1960, p. 332).

Para o malogro da iniciativa de Thiers, muito colaborou a população de Paris, principalmente as mulheres dos bairros operários. Essas, que já se destacavam no Comitê Central Republicano de Defesa Nacional dos Vinte Distritos de Paris, tiveram papel de relevo na mobilização da própria Guarda Nacional. Foram as mulheres que, em grupos ou individualmente, chamaram a atenção dos batalhões - quer por meio de palavras de ordem, ou simplesmente do vozerio atroante que das ruas chegava aos quartéis - e alertaram aqueles que, de armas em punho, frustraram as intenções do governo.

Relatou Jules Vallès (1986, p. 143), principal figura do jornal Cri du Peuple, sobre a participação das mulheres nas jornadas:

Mulheres por toda a parte. - Grande sinal!

Quando as mulheres se misturam às lutas, quando a dona de casa empurra seu marido, quando arranca a bandeira negra que envolve a marmita para exibi-la pela rua, eis que o sol aparece por sobre a cidade em revolução.

Imagem poética, mas nem por isso menos verdadeira.

\section{Raízes do federalismo revolucionário e a instituição da Comuna de Paris}

Para Proudhon, o espírito do absolutismo havia revivido nos decretos jacobinos da Convenção. O jacobinismo tinha sido muito mais demagógico que popular e, naquele momento, no contexto de 1848, ao que tudo indicava, não tinha se corrigido desse mal de origem.

Era o conteúdo centralizador e de tutela política absoluta da sociedade que incompatibilizava ainda mais o "neo"-jacobinismo, em seus diversos matizes, com as ideias de Proudhon. Característica essa que, ainda segundo ele, levaria os mais moderados ao "governismo" e os mais radicais à "ditadura". Proudhon, inversamente, enxergava formas mais seguras para se atingir o socialismo: na autonomia econômica da classe operária - só possível através do controle das unidades produtivas (fábricas, oficinas etc.) - e na 
emancipação política, por meio do federalismo, portanto contra o Estado. Igualmente, ele rejeitava os modelos derivados do jacobinismo primitivo: a centralização política na forma do Estado e a subordinação econômica levada a efeito pelo mesmo, ainda que sob o argumento da "soberania popular".

Em reforço a essa sua tese, Proudhon (1947) afirmava:

Empreender uma crítica sábia e profunda, proceder metodicamente ao descobrimento das leis sociais; isso supõe muitos estudos, um hábito de abstração, um espírito metódico, pouco compatível com o traço declamatório dos jacobinos.

E ainda:

A Montanha, fazendo sem sabê-lo ecletismo democrático e social, convertia-se em puramente doutrinária. Seu pretenso socialismo, contra o qual eu pouco podia fazer, não foi mais que uma filantropia embusteira cuja boa intenção apenas cobria sua esterilidade. É o que os montanheses teriam percebido se não estivessem mergulhados em suas esperanças governamentais, completamente iludidos. (Proudhon, 1947, p. 160)

Por outra parte, Proudhon encontrava qualidades no Partido da Montanha, ou, pelo menos, em uma parte deste, principalmente no que se referia à força que podia emprestar ao socialismo.

No seu livro Du Principe Fédératif et de la Nécessité de Reconstituer le Parti de la Révolution - escrito "a propósito de um artigo sobre a Itália no qual defendia a federação contra a unidade" (Proudhon, 1996, p. 31) e, ainda, no que dizia respeito ao projeto republicano, ou "democrático", de Garibaldi e Mazzini, pela via unitarista - Proudhon argumentou segundo as seguintes premissas:

Coisa estranha! Foram homens que levaram a bandeira da democracia que tomaram a seu cargo e responsabilidade a grande obra monárquica; e são os príncipes, doravante absolutos, que invocam o direito e a liberdade. Foi assim que os revolucionários italiotas se tornaram monárquicos e os príncipes federalistas. [...] Mas que não se fale então mais de liberdade ou de república: a Itália, dizendo adeus à sua tradição federal, declara-se ipso facto retrógrada. O seu princípio é doravante o mesmo que o dos velhos Césares, a menos que não seja o da monarquia burguesa, centralista e corruptora, onde a burocracia substitui a união das comunas, e o feudalismo financeiro, a federação agrícola e industrial. (p. 113) 
Segundo Proudhon, a mesma mentalidade neojacobina que acabara por favorecer o Império na França - sacrificando o ideal republicano (que só podia ser federalista) em favor do unitarismo - reproduzia-se na estratégia democrática dos italianos. A atitude dos revolucionários republicanos, que só fizera fortalecer ${ }^{7}$ o projeto unitarista e monárquico de Victor Emanuel, era, portanto (guardadas as proporções), semelhante àquela que haviam assumido alguns dos democratas na França.

Sobre o erro metodológico dos neojacobinos, Proudhon insistia:

Os políticos da velha escola mantiveram e mantêm ainda hoje que o melhor caminho a seguir, para a revolução social, é começar pelo governo, à parte ocupar-se de seguida, sem pressa, do trabalho e da propriedade. Com a recusa de competência da democracia depois de ter suplantado a burguesia e anulado o príncipe, o que devia acontecer aconteceu. $\mathrm{O}$ império veio impor silêncio a esses faladores sem planos; a revolução econômica fez-se no sentido inverso das aspirações de 1848, e a liberdade foi comprometida. (Proudhon, Do Princípio Federativo... 1996, p. 90)

Ele era enfático ao defender a primazia da revolução econômica e o perigo das tomadas de poder político, sem a emancipação da classe trabalhadora através do controle da produção. Devia ser assim, tanto no campo como nas cidades, por meio do fenômeno que chamava de "Federação Agrícola-Industrial".

Ao insistir na questão da configuração das nações, Proudhon defendia que as fronteiras nada mais eram que convenções políticas, feitas, muitas vezes, à revelia das pequenas nacionalidades e mesmo contra elas. Opunha o federalismo, capaz de conciliar os diversos povos europeus sufocados por Estados imperiais, ao unitarismo que arbitrava a prevalência de determinados povos sobre outros.

Na mesma direção, em 1870, Bakunin, valendo-se de alguns inconvenientes do sistema confederal suíço, manifestou sua desaprovação diante dos projetos de centralização política. Criticava a unidade coercitiva, apontando seus limites quanto à emancipação do povo e das forças organizadas, oriundas das camadas exploradas da sociedade. Segundo esse juízo, o caso da Suíça (que cabia generalizar para melhor explicitar o seu sistema de pensamento) caracterizava-se enquanto:

[...] um governo republicano, é verdade, mas apesar disso não é menos governo, e todo o poder político, qualquer que seja a dominação e a forma exterior, encontra-se animado por um ódio natural, instintivo, para 
diminuir e aniquilar, lenta e violentamente, segundo as circunstâncias e o tempo, a espontaneidade das massas governadas, e esta negação da liberdade se estende sempre e por todas as partes tanto quanto as condições políticas e sociais do espírito das populações o permitam. (BAKUnin, 1979, t. IV, p. 210)

E ainda:

Quem diz poder político, diz igualmente dominação. Mas onde existe a dominação deve haver necessariamente uma parte mais ou menos grande da sociedade que é dominada, e os que são dominados detestam naturalmente os que os dominam, assim como os que dominam devem necessariamente reprimir e por conseguinte oprimir os que estão submetidos à sua dominação. [...] Isso é o que explica também por que e como homens que foram democratas dos mais vermelhos, rebeldes furibundos, quando estavam na massa dos governados, se convertem em conservadores excessivamente moderados quando chegam ao poder. (BAKUNIN, 1979)

Ao resgatar as conquistas da Revolução de 1848, na Suíça, Bakunin argumentou que o Partido Radical - que teria emergido após as agitações daquele período - acabou por se tornar liberticida ao centralizar o poder político, subordinando os cantões aos arbítrios de um núcleo administrativo com escassa representatividade. E que, ao contrário, apenas as unificações econômicas - aquelas que facilitaram o avanço e o progresso das instituições produtivas e deram à classe trabalhadora a possibilidade de uma articulação em todo o território ${ }^{8}$ foram de fato emancipadoras. Contra a centralização política, ainda segundo ele, deviam os cantões reivindicar sua autonomia, invertendo, assim, a estrutura piramidal que dava ao Conselho Federal poder de pressão sobre as unidades cantonais espalhadas pelo país. Garantida a autonomia, proclamava, seria possível até mesmo a união de cantões - "penetrados pelo espírito de liberdade" contra os demais "reacionários" - em questões de opinião e legislação nacional. Era, em grande medida, a fórmula mais claramente delineada por Proudhon e aplicada ao contexto por Bakunin.

No caso da Comuna de Paris, nos dias que se seguiram ao 18 de março (23 e 24 de março), a Internacional - em acordo com a Federação das Câmaras Sindicais e após a redação de um manifesto - passou a apoiar 
formalmente, na qualidade de força coletiva organizada, o Comitê Central. O texto conclamava:

\section{Conselho federal das seções parisienses}

Trabalhadores,

Uma longa sequência de reveses, uma catástrofe que parece levar à completa ruína de nosso país, tal é o balanço da situação criada na França pelos governos que a dominaram. Perdemos as qualidades necessárias para nos erguermos contra essa degradação?

Estamos degenerados a ponto de suportar com resignação o despotismo hipócrita daqueles que nos entregaram ao estrangeiro e não recuperar a energia senão para tornar nossa ruína irremediável pela guerra civil?

Os últimos acontecimentos demonstraram a força do povo de Paris; estamos convictos de que um entendimento fraternal logo demonstrará sua sabedoria. $\mathrm{O}$ princípio de autoridade é doravante impotente para restabelecer a ordem na rua, para fazer renascer o trabalho na oficina e essa impotência é sua negação.

A insolidariedade dos interesses criou a ruína geral, engendrou a guerra social; é à liberdade, à igualdade, à solidariedade que é preciso pedir para assegurar a ordem sobre novas bases, para reorganizar o trabalho que é condição primeva.

Trabalhadores, a revolução comunal afirma esses princípios, ela afasta toda causa de conflito no futuro. Hesitareis dar-lhes vossa sanção definitiva?

A independência da Comuna é a garantia de um contrato cujas cláusulas livremente debatidas farão cessar o antagonismo das classes e assegurarão a igualdade social. Reivindicamos a emancipação dos trabalhadores, e a delegação comunal é sua garantia, pois ela deve fornecer a cada cidadão os meios de defender seus direitos, controlar de uma maneira eficaz os atos de seus mandatários encarregados da gestão de seus interesses e determinar a aplicação progressiva das reformas sociais. A autonomia de cada comuna elimina todo caráter opressivo a suas reivindicações e afirma a República em sua mais elevada expressão.

Combatemos, aprendemos a sofrer por nosso princípio igualitário, não poderíamos recuar agora que podemos ajudar a colocar a primeira pedra do edifício social. O que pedimos?

A organização do crédito da troca, da associação a fim de assegurar ao trabalhador o valor integral de seu trabalho. A instrução laica e integral, o direito de reunião e associação, a liberdade absoluta de imprensa, a liberdade do cidadão; a organização do ponto de vista municipal dos serviços de polícia, de força armada, de higiene, de estatística etc. 
Trabalhadores, fomos ingênuos com nossos governantes, nós nos deixamos enganar em seu jogo quando acarinhavam e reprimiam alternadamente as faç̧ões cujo antagonismo assegurava sua existência. Hoje o povo de Paris é clarividente, recusa-se a esse papel de criança dirigida pelo preceptor, e nas eleições municipais, produto de um movimento do qual ele próprio é o autor, recordará que o princípio que preside à organização de um grupo, de uma associação, é o mesmo que deve governar toda a sociedade, e como rejeitaria todo administrador, presidente imposto por um poder fora de seu seio, ele rejeitará todo prefeito, todo governador imposto por um governo estrangeiro a suas aspirações.

Afirmará seu direito, superior ao voto de uma assembleia, de permanecer senhor em sua cidade e constituir como lhe convém sua representação municipal sem pretender impô-la aos outros. Domingo, 26 de março: estamos convictos de que o povo de Paris manterá a honra de votar a favor da Comuna.

Os delegados presentes na sessão da noite de 23 de março de 1871. (Apud DolléAns, 1960, p. 337)

Participaram da reunião que deliberou pelo documento, além de outros, Frankel, Theisz, Demay e Aubry.

O manifesto internacionalista dava à Comuna o seu primeiro programa, com diretrizes mais claras e uma orientação socialista. Os que haviam permanecido à margem - alguns, inclusive, desconfiados de tratarse apenas de mais um movimento político - alteravam então sua posição. Tudo indicava que a Guarda Nacional que, em outras circunstâncias, negara seu apoio ao povo, estava agora firme e cética diante das promessas dos membros do governo; dera provas concretas dessa disposição. Além disso, mesmo que sob os influxos do patriotismo, acabara por esposar as premissas desde sempre defendidas pela Internacional na França. Diferente dos demais membros da Internacional, ainda que na condição de indivíduo, Varlin já compunha o Comitê Central da Guarda Nacional, desde os primeiros momentos da organização dessa instância, em fevereiro.

De 18 de março até a posse dos primeiros delegados da Comuna, em 28 do mesmo mês, o Comitê Central tomou para si as responsabilidades administrativas de Paris; os indícios que já vinham se anunciando pelas evidências, agora, concretizava-se, formalizava-se.

As eleições aconteceram no dia 26 , sem incidentes de grande significado. As urnas contabilizaram 229.167 votos (em um universo de 485.569 inscritos e em condições de votar), número esse, aliás, maior que dos pleitos 
municipais de 1870 . Os resultados deram a saber aos parisienses o nome de 80 novos representantes. Desses, 25 eram operários e, ainda dentro deste acanhado universo, eram também minoritários os internacionalistas. $\mathrm{O}$ resultado do escrutínio, que se encerrou dois dias depois, concedeu a representação a Varlin, Theisz, Avril, Assi, Langevin, Champy, Duval, Chalain, Camélinat, Malon, Amouroux, Pindy, Frankel, Dereure, Clément, Gérardin, A. Aranud, Clémence, Demay, Descamps e J. Dupont - todos envolvidos na organização dos operários desde 1868 - e ainda a outros, muito próximos ao grupo de socialistas revolucionários, como Beslay, Jourde, Vaillant, J. Vallès, Auguste Jean-MarieVermorel, Lefrançais, C. Longuet, G. Courbet e E. Pottier (DolléAns, 1960, p. 339). Os demais eleitos, maioria numérica, eram de origens diversas: blanquistas de todos os matizes, jacobinos, retóricos, membros dos clubes vermelhos, jornalistas radicais, além de uma quantidade importante de tendências indefinidas.

As regras para as eleições, no entanto, tinham sido modificadas. Cada grupo de 20 mil habitantes e fração de 10 mil elegia um representante para a Comuna, em um total de 90 . Tal critério levava em consideração o número de votantes e não, como era antes, o limite de três representantes para cada bairro. Dessa forma, desprezava-se o número de habitantes em cada parte da cidade, fato que atribuiria aos bairros mais densamente povoados (dos operários, portanto) maior representatividade. Outra novidade ficava por conta do número elevado de eleitores que havia atendido ao chamado para os pleitos nos bairros burgueses. Resultado atingido, muito provavelmente, por ter sido a convocação assinada pelos deputados do Sena e administradores.

Além disso, os vencimentos aos quais faziam jus os delegados eleitos não deviam superar a média salarial de um operário qualificado; sendo igualmente estabelecida a regra de revogabilidade da representação, a qualquer momento, por improbidade ou inoperância política do delegado.

Com um público estimado em 200 mil pessoas, a Comuna tomou posse em 28 de março, inaugurando uma nova fase, a da federação. Lissagaray a resumiria como: "A unidade da colmeia, não do quartel. A célula orgânica da República francesa é o município, a Comuna” (DolléAns, 1960, p. 111). Frase que bem podia ser tomada como epígrafe dos decretos do Comitê Central. Este, logo a seguir à posse dos delegados, na figura de um de seus representantes, entregou à Comuna os poderes políticos e administrativos de Paris.

Para seu funcionamento, a fim de tratar das diversas áreas, a Comuna criou as seguintes comissões: Guerra, cujos membros eram: Pindy, Eudes, Bergeret, Duval, Chardon, Flourens e Ranvier; Finanças: V. Clément, Beslay, 
Varlin, Jourde e Régére; Segurança Geral: R. Rigault, Ferré, Assi, Cournet, Oudet, Chalain e C. Gérardin; Ensino: Vallès, Goupil, Urbain, A. Lefévre, A. Leroy, Verdure, Demay e Robinet; Subsistência: Ostyn, Parisel, E. Clément, Dereure, J.-B. Clément, F. Henri e Champy; Justiça: Ranc, Protot, L. Meillet, Vermorel, Ledroit e Babick; Trabalho e Trocas: Theisz, Malon, Frankel, C. Dupont, Avrial, Loiseau-Pinson, E. Gérardin e Puget; Relações Exteriores: Delescluze, Ranc, P. Grousset, U. Parent, A. Arnould, A. Arnaud ${ }^{9}$ e C. Gérardin; e Serviços Públicos: Ostyn, Billioray, J.-B. Clément, Martelet, Mortier e Rastoul. A Comissão Executiva, para tratar de assuntos urgentes, recebeu para a sua composição os seguintes nomes: Eudes, Tridon, Vaillant, Lefrançais, Duval, F. Pyat e Bergeret (LefrançAIs, 2001, p. 193).

A Comuna, pelo exposto, governava de fato por uma estrutura federativa, através da qual os delegados dos 20 distritos formavam a comissão executiva e as diversas comissões de trabalho. Era, por força de seu desenho e concepção, um órgão simultaneamente executivo e legislativo. Rompia com a divisão clássica tripartite dos poderes, apresentava-os descentralizados, embora funcionassem dentro da mesma esfera. Sem outro órgão, além dela própria, que lhe impusesse qualquer limite, funcionava sob a auspiciosa aclamação das forças que lhe davam sustentação. A aparente centralização de poderes, ao menos nas primeiras semanas, era, na realidade, um sutil equilíbrio de funções repartidas entre os componentes das comissões, de forma a possibilitar a gestão das questões de interesse social, político e econômico. Configurava-se em uma tentativa, em potência, de se instituir um tipo de poder indiviso, a partir do qual as funções sociais, antes atribuídas por uma ordem de privilégios, se diluíssem na representação horizontal, admitida e patrocinada pelo conjunto da sociedade (BAKUNIN, 2009).

\section{O FEDERALISMO DA MINORIA E A COMUNA NA PROVÍNCIA}

A despeito de ter a Comuna de Paris adotado a organização federalista, esta não compunha a tradição política da maioria dos delegados. Muitos blanquistas mantinham em seus periódicos colunas dedicadas à crítica ao federalismo. Gustave Tridon, talvez o mais obstinado oponente dos federalistas, dizia ser essa forma de organização uma engenhosa fórmula girondina, cujo objetivo era distrair o povo e impedir a centralização do poder revolucionário, único capaz de derrotar as forças monárquicas e burguesas. $\mathrm{O}$ federalismo, ainda segundo ele, teria ampliado o seu prestígio nos meios revolucionários durante o II Império, ao ser utilizado como panaceia contra o centralismo bonapartista. Para Tridon, a verdadeira Comuna de 1793 - que 
havia triunfado sobre a Assembleia Constituinte, a Convenção jacobina e mesmo sobre o Comitê de Salvação Pública - era aquela dirigida pelo povo com apoio de Hébert, Chaumette e Anarcharsis Clootz (Koechlin, 1965, p. 90). No geral, os blanquistas, em menor ou maior intensidade, permaneceram convictos da ideia, segundo a qual os eventos de 1871 prendiam-se e estavam subordinados ao movimento de 1793.

Gaston Da Costa sustentava, na mesma oportunidade, que nem os jacobinos, nem os federalistas haviam compreendido com precisão a essência da Comuna. Aqueles por incapacidade, uma vez que eram apenas visionários e sonhadores, vitimados por suas utopias; e estes, os federalistas, por terem acreditado sintetizar o poder constituído em si, cometendo assim o crime de usurpação.

Nos discursos dos jacobinos, não era difícil identificar a prevalência das teses centralistas. Perseguiam a memória da Convenção, do protagonismo de Robespierre, do projeto de um Estado forte e unido no mesmo objetivo. Concepção, aliás, compartilhada por republicanos muito respeitados, como Victor Hugo e mesmo Garibaldi.

Com base no exposto, o centralismo revolucionário baseava-se na convicção de que para haver progresso histórico (premissa, diga-se a propósito, comum a blanquistas e jacobinos) era fundamental a ação violenta de uma elite.

Cabe aqui, contudo, uma indagação. Que motivos, além do exposto anteriormente, teriam levado seguidores de Robespierre e de Hébert a assinar os decretos e proclamas da Comuna de inspiração oposta às suas postulações? A aceitar, sob um silêncio obsequioso, as reiteradas medidas orientadas pelo federalismo? Atitude tanto mais curiosa, sabendo-se ser o grupo centralista majoritário.

Para Koechlin, a maioria centralista tinha consciência das peculiaridades entre as situações de 1793 e 1871 . Apesar da tentadora possibilidade de se estabelecer paralelos entre as duas conjunturas, no que dizia respeito à importância de Paris e a concentração das forças revolucionárias na capital, as dificuldades em 1871 eram outras. Além da derrota para a Prússia, existia também a Assembleia de Versalhes, composta principalmente pelas forças conservadoras, com o apoio de parte significativa da província. Centros importantes - como Bordeaux, Marselha e Lyon - não apenas não tinham completado as suas revoluções, como ainda experimentavam um isolamento que os impedia de tomar partido de Paris. Nessas cidades, os prefeitos, verdadeiros prepostos de Versalhes, passaram a ser considerados os piores inimigos da revolução. O republicanismo revolucionário, até ele, por conta 
dos fatos, aproximou-se pela primeira vez do federalismo. Ademais, por força da Guerra Civil, Paris encontrava-se ilhada do resto do país, o que, na prática, acabaria por empurrá-la para uma forma administrativa mais autônoma. Assim, qualquer iniciativa no sentido da centralização política para toda a França não teria outro significado senão teórico e de propaganda (Koechlin, 1965, p. 94-95).

Sobre o isolamento de Paris, cabe mencionar que em diferentes partes da França, ainda em setembro de 1870 (portanto, antes mesmo da capital), outras tentativas de instituição de comunas revolucionárias tiveram lugar: em Lyon, Marselha e, no ano seguinte, em Creusot, Saint-Etienne, Toulouse e Narbonne; além de outras experiências ainda mais efêmeras em Béziers, Perpignan, Limoges e Cette. No departamento de Limousin, outras cidades ainda manifestariam apoio a Paris, como Tulle, Solignac e Aubusson, algumas delas com a ocupação de suas respectivas prefeituras. Mesmo na Argélia, território colonial, a Comuna encontrou alguns entusiastas.

Em todas essas tentativas, mais longevas, em que se verificava a presença da Guarda Nacional apoiando o movimento, a resposta das tropas leais ao governo de Versalhes fora a mesma: massacres e prisões.

\section{Guerra Civil, comissões e Realizações}

Mas além das dificuldades inerentes de adaptação a uma nova forma de organização social e política, contava para os delegados da Comuna o fato de Paris encontrar-se em situação de Guerra Civil, circunstância, aliás, confirmada pelo decreto de Thiers de 10 de abril. Essa realidade dificultava, principalmente, a resolução das demandas relacionadas aos internacionalistas, aquelas típicas de um "governo social". Inversamente, favorecia bastante as tradições jacobinas, blanquistas e radical-republicanas uma vez que essas preferiam entender a Comuna como a mobilização de um corpo coletivo único e igualitário, como partido político de massas que envolvia e centralizava toda a população (GonzÁLEZ, 1989, p. 80).

$\mathrm{Na}$ realidade, desde o dia 2 de abril, as forças de Versalhes haviam iniciado os bombardeios à capital. Logo nos primeiros confrontos, os comunalistas amargaram derrotas que não cessaram nas semanas seguintes. A Comissão de Guerra - em que se encontravam basicamente blanquistas e jacobinos -, apesar de ter contado com o concurso de vários oficiais, não foi capaz de organizar uma defesa satisfatória. Fato que foi, não apenas denunciado nas assembleias da Comuna, realizadas no Hôtel de Ville, como ainda viria a colaborar para a entrada dos versalheses na cidade, em 22 de maio. 
As demais comissões - ainda que em guerra tivessem realizado alguns prodígios, se considerada a conjuntura especial - foram em tudo auxiliadas por comitês populares, organizados nos bairros e distritos ; como o Comitê Central da União das Mulheres que (através de um documento público, datado de 12 de abril) deu-se a conhecer à Paris insurreta. ${ }^{10}$ Evocando o internacionalismo, ao citar os movimentos de trabalhadores na Alemanha, Itália, Espanha, Rússia, Irlanda e Polônia, o documento, intitulado "Apelo às Mulheres", salientava:

Nossos inimigos são os privilegiados da ordem social presente, todos aqueles que sempre viveram de nosso suor, que sempre engordaram com a nossa miséria!

Eles viram o povo se levantar, gritando: - Nenhum dever sem direito, nenhum direito sem dever! - Desejamos o trabalho, mas para guardar o produto dele! - Chega de exploradores, chega de senhores! - O trabalho é o bem-estar para todos, o governo do povo por si mesmo - a Comuna viver livre trabalhando, ou morrer combatendo! (Apud DunoIs, 1969, p. 76)

Para além de um simples grupo de opinião e de intervenção ocasional, o Comitê Central da União das Mulheres foi, na realidade, um órgão suplementar à Comuna. Auxiliou Léo Frankel na Comissão do Trabalho e Trocas e, com ele, assinou os cartazes que foram afixados pela cidade, convocando para a "organização do trabalho das mulheres de Paris" na "União das Câmaras Sindicais Federativas de Trabalhadoras". O texto do "apelo" indicava, para 17 de maio, a escolha de delegadas para a formação da Câmara Federal (Bruhat et al., 1970, p. 188).

O Comitê - por força da determinação daquelas que no seu interior atuavam - orientava, assim, a ação de muitos grupos de mulheres que nos bairros davam anonimamente consequência às iniciativas sugeridas pela Comuna. Socialistas, blanquistas ou simplesmente republicanas, as principais figuras desse órgão eram: Louise Michel, Theresa Collin, Aglaë Jarry, André Léo, Noémie Perrier, Noémie Reclus, Adele Gauvin, Marie Greenery, Elie Ducoudray, Paule Mink, Mme. Allix, Victorine Eudes, Marie Leroy e Marie Ferré. Por meio do Comitê, organizaram refeitórios públicos, escolas, instituíram um serviço permanente de ambulâncias e fundaram clubes, como o de Saint-Eustache, para fins de agitação política e troca de impressões sobre a conjuntura particularmente delicada, compartilhada por todas elas. E, em diversas oportunidades, pegaram em armas e compuseram o setor mais vibrante das barricadas. 
Funcionavam nos bairros, ou em apoio direto ao Hôtel de Ville, outras federações cujos objetivos eram bastante específicos. Gustave Courbet, por exemplo, esteve à frente da Federação dos Artistas (AnTliff, 2009, p. 35), coletivo organizado em 13 de abril, com o fito de garantir a integridade do patrimônio artístico já existente, articulando-o com os "elementos do presente", na intenção de "regenerar o futuro pela educação"e projetar uma estética engajada, adequada à nova ordem revolucionária. Era um fervoroso adepto da filosofia de Proudhon (Reszler, 2009) e também seu íntimo. Em atitude francamente solene e devotada, para que não houvesse dúvida sobre a sua apreciação dos fatos, no dia 6 de abril, através de uma carta aberta "aos artistas de Paris", escreveu que, na mesma medida de serem os operários os "apóstolos" da revolução, Proudhon era seu "Cristo" (Antliff, p. 34). Eleito delegado da Comuna no dia 26 de março, Courbet atuou não apenas na Federação dos Artistas, mas também na Comissão de Educação. Foi ainda o principal responsável pela execução da ordem da Comuna que, no dia 12 de abril, havia decidido pela derrubada da Coluna de Vendôme.

Estavam ligados à Federação dos Artistas figuras como o proudhoniano Eugène Pottier, ${ }^{11}$ autor dos versos ${ }^{12}$ que, combinados à melodia de Pierre Degeyter, se tornariam célebres sob o título de $A$ internacional. Ainda outros importantes artistas e cientistas uniram-se em favor das mudanças, segundo a Federação, de importância capital para Paris.

Ainda que premidos pelas enormes dificuldades, os comunalistas foram capazes de colocar em marcha inúmeras medidas.

a) Políticas: supressão do exército permanente e substituição deste pelas milícias cidadãs; separação entre a Igreja e o Estado; abolição dos cultos religiosos; ${ }^{13}$ estabelecimento da elegibilidade dos estrangeiros; adoção da bandeira vermelha, símbolo da "Unidade federativa do gênero humano" e, do calendário revolucionário de 1789.

b) Sociais e trabalhistas: ajuste dos rendimentos dos funcionários públicos de acordo com os salários dos operários manuais; supressão do trabalho noturno nas padarias; reorganização do trabalho feminino; arbitramento da administração comunal no que se referia aos vencimentos dos trabalhadores nas suas diversas funções; extensão do prazo para o pagamento dos aluguéis e a adaptação, para novos termos, dos contratos anteriores; moratória de três anos para as dívidas; devolução de itens penhorados por operários que não excedessem o valor de 20 francos, principalmente no caso de instrumentos de trabalho e livros; fim das vendas de objetos do Mont-de-Piété; instituição de pensão para os federados feridos, suas viúvas e órfãos, mesmo que ilegítimos; fim das multas sobre os salários; 
fixação dos salários em no máximo 6 mil francos anuais, definidos também os vencimentos dos professores em 2 mil francos; disponibilização das oficinas abandonadas aos trabalhadores, sob o controle de suas câmaras sindicais; padronização das 10 horas para as jornadas de trabalho; estímulo aos ateliês cooperativos no prédio do Louvre, encarregados de reparar e fabricar armas; instituição de um crédito estatal destinado à criação de associações operárias; mutualidades, com taxas de juros anuais de cinco por cento; destinação dos prédios vazios aos trabalhadores sem moradia, ou aos desalojados em virtude dos bombardeios; e, ainda, o estabelecimento da gratuidade na educação pública que deveria ser laica e politécnica.

c) Jurídicas: confisco de bens de raiz; abolição dos processos ordinários, dando a ambas as partes direito de voz e ampla defesa; organização de um tribunal civil em Paris; eleição para a magistratura; organização do júri e julgamento pelos pares; além da encomenda de um estudo sobre os manicômios judiciários.

Os pontos destacados pela Comuna faziam recordar as exigências expressas no affiche rouge, publicado em 13 de setembro de 1870, pelo Comitê Central Republicano de Defesa Nacional dos Vinte Distritos de Paris e de outros, como o de 5 de janeiro de 1871, afixados nos muros de Paris pelo mesmo grupo.

\section{O FIM E A REPRESSÃO}

No dia $1^{\circ}$ de maio, a "maioria" da Comuna reeditava (de acordo com a "minoria") uma fantasmagoria anacrônica. Retornava o Comitê de Salvação Pública cujo objetivo era, de forma mais centralizada, articular as ações (não apenas, mas principalmente) militares. Os membros da minoria - quase todos internacionalistas e adeptos do federalismo - não se limitaram a votar contra tal iniciativa, como também, uma vez que haviam sido derrotados, lançaram um manifesto com diversas críticas. Tal situação aumentou as inúmeras dificuldades já existentes, tanto mais por não ter o referido Comitê alcançado qualquer êxito em suas insuficientes medidas.

No domingo, dia 21 de maio, os versalheses já se preparavam para invadir Paris (intento que se confirmaria no dia seguinte) quando, quase sem enfrentar resistência, infiltrados pelas várias aberturas nos portões, já eram suficientes para formar duas colunas. Os versalheses haviam optado por uma entrada silenciosa e, por onde passavam, iam deixando os corpos dos guardas nacionais degolados. 
Diante da ineficiência da defesa concebida pelo Comitê de Salvação Pública, os acontecimentos empurraram para as barricadas os internacionalistas Malon, Lefrançais, Varlin e outros. Estes se envolveram diretamente na luta em diferentes pontos de Paris, uma vez que não lhes cabia nenhuma tarefa oficial para a defesa, apartados como estavam do Comitê de Salvação Pública e da Comissão da Guerra, foram para os bairros tentar organizar a resistência. Louise Michel, que já era quase um mito entre os operários, permaneceu em Montmartre; as demais componentes do Comitê Central da União das Mulheres - Nathalie Lemel, Blanche Lefèvre e Elisabeth Dimitrieff - reforçaram as barricadas da place Blanche; e André Léo as de Batignolles, no $17^{\circ}$ distrito (Michel, 1971, p. 61). Pode-se afirmar que, quando o Comitê decidiu organizar a defesa, a população e os guardas nacionais já tinham adiantado o trabalho a ser realizado nas barricadas.

Durante toda a semana, de 22 a 28 de maio, a "Semana Sangrenta", a população lutou na tentativa desesperada de escapar ao jugo de Versalhes. Os comunalistas, ou federados, como também eram conhecidos, pagaram um alto tributo por mais essa ousadia. Foram derrotados pela massa de soldados que o acordo entre Thiers e Bismarck, assinado em 10 de maio, havia colocado nas fileiras do exército da reação. Haviam tombado 4 mil comunalistas no confronto direto, nas barricadas, e outros, mais de 20 mil, foram fuzilados pelas tropas de Thiers. ${ }^{14}$ Os julgamentos sucederam os fuzilamentos, com deportações e penas variadas de prisão. As punições se arrastaram por anos, os juízes ad hoc não cessaram de proferir veredictos. A experiência federalista foi arrastada na lama por todo o continente, seus cadáveres expostos em cartazes e fotografias e seus escombros exibidos nos jornais.

Sobre a Comuna de Paris teria dito Bakunin:

Sou um partidário da Comuna de Paris, que, por ter sido massacrada, sufocada no sangue pelos carrascos da reação monárquica e clerical, tornou-se ainda mais viva, mais poderosa na imaginação e no coração do proletariado da Europa; sou seu partidário, sobretudo porque ela foi uma negação audaciosa, bem pronunciada, do Estado. (BAKUnIN, 2008, p. 118)

E ainda Marx:

Eis o seu verdadeiro segredo: a Comuna era, essencialmente, um governo da classe operária, fruto da luta da classe produtora contra a classe apropriadora, a forma política afinal descoberta para levar a cabo a emancipação econômica do trabalho. [...] Quando a Comuna de Paris tomou em suas próprias mãos a direção da revolução; quando, pela 
primeira vez na história, os simples operários se atreveram a violar o monopólio de governo de seus "superiores naturais" e, em circunstâncias extraordinariamente difíceis, realizaram seu trabalho de modo modesto, consciente e eficaz, com salários o mais alto dos quais representava uma quinta parte da soma que, segundo uma alta autoridade cientifica, é o vencimento mínimo do secretário de um conselho escolar de Londres, o velho mundo contorceu-se em convulsões de raiva ante o espetáculo da bandeira vermelha, símbolo da república do trabalho, ondeando sobre o Hôtel de Ville. (Marx, 1977, p. 201)

Interessante notar que, muito provavelmente pela força de seus feitos, a Comuna conseguiu aproximar até mesmo posições polarizadas como as de Bakunin e Marx. Foi, na sua inteireza, uma experiência de autoinstituição (CAstoriadis, 2006, p. 174), um evento autônomo, não apenas por sua ousadia, mas por suas singularidades. Por tudo isso, tornou-se "uma linha divisória dos tempos - e, simultaneamente, dos pensamentos, costumes, curiosidades, leis e das próprias línguas - estabelecendo um antes e um depois, absolutamente antagônicos e aparentemente irreconciliáveis". ${ }^{15} \mathrm{Um}$ aspecto único da longa genealogia que ajudou a definir a democracia popular no século XIX.

“A LAND Without Masters": federalism in the Paris Cummune

AвSTRACT: This paper explores the origins of French federalist tradition, particularly during the Paris Commune (1871). It seeks to illustrate the organizational forms adopted in Paris both prior and during the 72 days in which the city found itself amidst a revolutionary movement of tremendous social impact. This paper also examines the role played by members of the First International and how this renowned institution contributed to the formation of working class power in Parisian districts and neighbourhoods.

Key words: federalism, internationalism, Paris Commune, revolution, power worker.

\section{NOTAS}

1 Ver para tanto: Samis, 2011.

2 Apud Guillaume,1985, p. 74.

3 Informação obtida a partir de um relatório apresentado ao Bureau de Paris, em 20 de abril de 1870, e registrada por Édouard Dolléans (1960, p. 286) e Jean Maitron et al. (199_) CD-ROM. 
4 Segundo Gustave Lefrançais (2001, p. 144), esse movimento já estava em curso desde 24 de fevereiro de 1871.

5 Revolta de parte da Guarda Nacional com a participação ativa de setores blanquistas. A iniciativa, assim como a de 31 de outubro do ano anterior, esbarrou na reação das forças leais ao governo (Henri MARTin, 1906, p. 19).

6 Referência à defesa de Paris durante o cerco prussiano e a posição reticente dos generais Trochu e Ducrot, no Conselho de Guerra, em 21 de janeiro, no que se referia a uma nova tentativa, reclamada pela Guarda Nacional e maires dos diversos distritos da capital, de rechaçar o inimigo. Sobre o episódio, Jules Favre escreveu a Gambetta que: "A rendição de Paris, não implica a perda da França; mercê dos vossos esforços o país acha-se animado de um espírito patriótico que há de salvar, sejam quais forem as circunstâncias". Após a passagem do comando ao general Vinoy, no dia seguinte, os clubes e parte da Guarda Nacional levantaram-se contra o governo (Ibidem, p. 18).

7 Segundo Milza e Berstein sobre a posição dos republicanos: "Cavour triunfa então na última fase da preparação da unidade italiana. Enquanto que, consciente do malogro da corrente democrática e republicana, uma vasta fração da pequena burguesia aceita ligar-se com os seus partidários à monarquia de Saboia, Gioberti converte-se com seus partidários à solução piemontesa e Daniel Manin escreve, antes de morrer, a Victor Emanuel: 'Fazei a Itália, que eu estou, e todos os republicanos patriotas estão, do vosso lado e convosco" (Berstein e Milza, 1997, p. 280).

8 Torna-se relevante destacar que, no seu tempo, Bakunin combatia as práticas descentralizadas do livrecambismo derivadas do receituário liberal burguês. A centralização econômica era, portanto, simultaneamente pré-condição e corolário da expropriação dos meios de produção pelos operários e camponeses.

9 Segundo o índice de nomes citados, que consta do livro de Gustave Lefrançais, Antoine Arnaud era membro do Conselho Geral da AIT (LefrançAis, 2001, p. 74).

10 Apesar dos significativos avanços verificados durante a Comuna, as mulheres permaneceram sem direito ao voto.

11 Pottier foi um dos signatários do apelo aos eleitores, elaborado e publicado pelo Comitê Central dos Vinte Distritos, em apoio ao Comitê Central da Guarda Nacional. Como membro da Câmara Federativa das Sociedades Operárias, engajou-se no projeto da Internacional para a Comuna e elegeu-se, pelo $2^{\circ}$ distrito, em 26 de março (РоттіER, 1966, p. 16).

12 Pottier dedicou essa obra a Lefrançais (Ibidem, p. 101).

13 As igrejas podiam funcionar na condição de manterem suas portas abertas a atividades políticas públicas nos horários alternativos aos cultos.

14 As autoridades versalhesas admitiram ter causado 17 mil mortes, não mais do que isso (Christiansen, 1998, p. 348). 
15 Definição de Chateaubriand do que representa uma revolução, interpretada desta forma por J.-P. Richard e citada por Decouflé com o seguinte complemento: "Atribui à revolução seu espaço fisíco originário: o espaço de um círculo cuja circunferência é traçada ao infinito por um arquiteto misterioso - um deus ou um povo" (DECOUfLÉ, 1970, p. 7).

\section{REFERÊNCIAS}

Antliff, A. Anarquia e arte: da Comuna de Paris à queda do Muro de Berlim. São Paulo: Madras, 2009.

Bakunin, M. Obras completas. Madrid: La Piqueta, 1979. t. IV.

BAKunin, M. A Comuna de Paris e a noção de Estado. O princípio do estado e outros ensaios. São Paulo: Hedra, 2008.

BAKUnin, M. Catecismo revolucionário e programa da sociedade da revolução internacional. São Paulo: Imaginário/Faísca, 2009.

Berstein, S.; Milza, P. (Coord). História do século XIX. Mem Martins: EuropaAmérica, 1997.

Bruhat, J. et al. La Commune de 1871. Paris: Éditions Sociales, 1970.

Castoriadis, C. Uma sociedade à deriva: entrevistas e debates, 1974-1997. Aparecida, SP: Ideias \& Letras, 2006.

Christiansen, R. Paris Babilônia: a capital francesa nos tempos da Comuna. Rio de Janeiro: Record, 1998.

Dalotel, A.; Faure, A.; Freiermuth, J-C. Aux origines de la Commune: le mouvement des réunions publiques à Paris 1868-1870. Paris: Maspero, 1980.

Decouflé, A. Sociologia das revoluções. São Paulo: Difusão Europeia do Livro, 1970.

DolléAns, É. Historia del movimiento obrero: 1830-1871. Buenos Aires: Editorial Universitaria de Buenos Aires, 1960.

Dunois, A. et al. Textos e documentos compilados e comentados. A Comuna de Paris. Rio de Janeiro: Laemmert, 1969.

Dupuy, R. La Garde Nationale: 1789-1872. Paris: Gallimard, 2010.

González, H. A Comuna de Paris: os assaltantes do céu. São Paulo: Brasiliense, 1989.

Guillaume, J. L'internationale: documents et souvenirs, 1864-1872. Paris: Éditions Gérard Lebovici, 1985. v. I.

Koechlin, H. Ideologías y tendencias en la Comuna de París. Buenos Aires: Editorial Proyección, 1965.

LefrançAis, G. Étude sur le mouvement communaliste à Paris, en 1871. Paris: Ressouvenances, 2001. 
Lissagaray, H. P-O. História da Comuna de Paris de 1871. São Paulo: Ensaio, 1991.

Maitron, J. et al. Dictionnaire Biographique du Mouvement Ouvrier Français. Paris: Les Edition de L'Atelier, [199-]. CD-ROM.

Martin, H. História de França. Lisboa: João Romano Torres Editor, 1906. v. IV.

Marx, K. A guerra civil na França. Textos. São Paulo: Alfa-Omega, 1977. v. I.

Michel, L. A Comuna. Lisboa: Editorial Presença, 1971. v. II

NoËL, B. Dictionnaire de la Commune. Paris: Flammarion, 1978. v. I e II.

PÉronnet, M. Revolução francesa em 50 palavras-chave. São Paulo: Brasiliense, 1988.

Pottier, E. Ouvres complètes. Paris: Maspero, 1966.

Proudhon, P-J. Confesiones de un revolucionario. Buenos Aires: Editorial Americalee, 1947.

Proudhon, P-J. Do princípio federativo e da necessidade de reconstruir o partido da revolução. Lisboa: Edições Colibri, 1996.

Reszler, A. A estética anarquista. Rio de Janeiro: Achiamé, 2009.

SAmis, A. Negras tormentas: o federalism e o internacionalismo na Comuna de Paris. São Paulo: Hedra, 2011.

VAllès, J. L’insurgé. Paris: Le Livre de Poche, 1986. 